\title{
Diversity of parasitic fauna of conventional rice ecosystem during kuruvai season at Annamalainagar, Tamil Nadu
}

\author{
C. Kathirvelu \\ Department of Entomology, Faculty of Agriculture, Annamalai University, Annamalainagar \\ - 608002 (Tamil Nadu), India \\ E-mail: ckathirveluau@gmail.com
}

\section{Article Info}

DOI:10.31018/jans.v11i1.1995 Received: January 18, 2019 Revised: February 21, 2019 Accepted: February 25, 2019

\section{How to Cite}

Kathirvelu, C. (2019). Diversity of parasitic fauna of conventional rice ecosystem during kuruvai season at Annamalainagar, Tamil Nadu. Journal of Applied and Natural Science, 11 (1): $164-167$ etc. The results of the diversity of parasitic fauna of conventional rice ecosyster vealed that a total of 889 parasitoids were collected through net sweep, 631 in trap, 534 in yellow pan trap and 308 in UV light trap during Kuruvai, 2012. Thirteen different agriculturally important parasitic families were collected and identified. Among the families collected, Ichneumonidae, Braconidae, Scelionidae and Chalcididae were found predominant. Dryniidae was recorded only in yellow pan trap. Among the collection methods employed, Net sweep was found to be the best in collection of parasitoids than other methods in conventional rice ecosystems.

Keywords: Diversity, Conventional ecosystem, Parasitic fauna, Rice.

\section{INTRODUCTION}

Rice, Oryza sativa L. is the stable food crop in the developing countries and is the food for over half of the world's population (Juliano, 1993). According to Dale (1994) over 800 species of insect pests damage rice plant in many ways although majority of them cause minor damage. About 20$30 \%$ of economic damage in rice crop is caused by number of insect pest species (Pathak and Khan, 1994). In India, rice crop is damaged by more than 300 species of insects. Out of which, 20 were recognized as the major pests (Pathak, 1997; Arora and Dhaliwal, 1996) that cause 21 to $51 \%$ yield loss (Singh and Dhaliwal, 1994).

The widely used insect pest control method in rice is the application of chemical insecticides that cause insecticide resistance development in insects, pollution in the environment and unwanted effect on the non-target organisms including predators, parasites and pathogens of target pests (Kiritani, 1979). Some insecticides disrupt the natural enemy fauna and induced resurgence of the target insect pests and lead to outbreaks of secondary pests (Heinrichs, 1994). Arthropod natural enemies like predators and parasitoids are often essential biological agents of various insect pests of rice ecosystem.

Ooi and Shepard (1994) stated that stable relationship between insect pests and their natural enemies in rice were evolved. In most instances, the species richness and abundance of natural enemy population may be grater that those of the pest populations, when little or no insecticides are used (Way and Heong, 1994). Determining the natural enemies and bio diversity of rice fields is the first step to success in biological control and IIPM (Integrated production and pest management) programmes. In many of the biological control programmes emphasis were given on promoting one or two premier natural enemies for the management of particular pests. In India, few attempts were made to record the incidence of rice insect pests and their natural enemies in Andhra Pradesh (Rao and Ali, 1976), Gujarat (Pandya et al., 1995), Karnataka (Naganagoud et al., 1999) Bihar (Rai et al., 2000) and Uttaranchal (Pushpakumari and Tiwari, 2005) Kerala (Ranjith et al., 2015) Pusa, Bihar (Shiriti Moses, 2018). In Tamil Nadu, especially Cuddalore District, a coastal tract is not studied well about the diversity of parasitoids in rice ecosystems. Considering the 
above facts, the present study was undertaken with an aim to gather and identify parasitoids from conventional rice ecosystem at Annamalainagar, Tamil Nadu by using various collection methods.

\section{MATERIALS AND METHODS}

The present study was carried out at Annamalai University Experimental Farm during kuruvai season in 2012. The rice variety ADT-36 was grown during Kuruvai following conventional practices like application of inorganic manures, pesticides, micronutrients etc. The parasitic insects were collected mainly by using the following methods.

Sweep net: The net design in the present study was according to Noyes (1982) where the perimeter was $1.2 \mathrm{~m}$ (about 45 inches) with a round frame. Nylon net material having very small mesh was used but it was almost transparent. The insects were picked up from the bag by an aspirator (pooter) in one hand, while the bag was held by another hand in a horizontal position and our head was at the entrance to the net. Because the bag was whitish and transparent, the most active insects move up into the upper part of the raised bottom of the net, there the parasiotoids were picked by using the aspirator, and hardly any parasitoid tried to escape by the entrance of the bag. The aspirator should be large enough to avoid condensation on the walls.

Malaise trap: Malaise traps are tent like intercept traps made of the fine mesh materials and used primarily for the collection of flies (Diptera) and wasps (Hymenoptera) although they catch many other flying insects. Collection of parasitoids was done without hindrance using Malaise trap and it was fabricated as per Townes (1972) with light modifications. The trap was $6 \times 3$ feet with two side opening and 4 feet at the back. The trap was erected with a support of wooden poles at each corner and at the peak in the front. Parasitoids and other insects hit the wall; fly upward to the peak of the trap and eventually find their way into a jar with killing agent, 75 per cent ethyl alcohol.

UV light trap: The light trap was in continuous operation during the season (June, 2012 to September, 2012) from $1800 \mathrm{hr}$. and switched off 600 $\mathrm{hr}$. Collections were made daily in the morning hours and parasitoids were separated and subjected to monitoring.

Yellow pan trap: Notable small insects as well as parasitoids and other groups of insects can be obtained with yellow pan trap. It works on the principle that many insects are attracted to yellow colour. The trap consists of a shallow tray plates or painted with bright yellow colour inside. They were sunk into rice field bunds, after the trays were filled with saturated salt solution, or with a $50 / 50$ mix of ethylene glycol and water (plus a few drops of detergent to break the surface tension). Pans containing the water or salt solution were kept for one or two days. After that, the content was sieved through a fine mesh sieve retaining only the insects. The retained specimens were thoroughly washed with running water to remove even the last traces of soap. The sieve on contains specimens was inverted over a petriplate containing 70 per cent alcohol and sorted out under a Carl Zeiss Stemi DV4 Stereo Zoom Microscope to recover only parasitoids.

All the above traps were set up in conventional ecosystem during kuruvai season and the parasitoids recovered were killed using ethyl acetate or 70 per cent ethyl alcohol. After killing, the collected parasitoids were either directly pinned using entomological pin or micro pins or card mounted according to the size of the parasitoids. Before card mounting, the specimens were removed from alcohol and dehydrated with 100 percent ethyl alcohol; otherwise the specimens were critical point dried, and relaxed using Hexamethyl disilazane (HMDS) (Brown, 1993). The collected specimens were sorted out and diagnosed upto family level using keys provided by Boucek (1988) and Ooi and Shepard (1994).

\section{RESULTS AND DISCUSSION}

Sweep net: Parasitoids collected in conventional rice ecosystem through sweep net during kuruvai season 2012 are presented in Fig.1 and 2. The results of the sweep net collection revealed that there was a maximum (74) number of parasitoids in $29^{\text {th }}$ standard meteorological week (SMW) followed by 73 numbers in SMW 33, out of 889 parasitoids collected in the entire season using sweep net. The parasitoids were identified and classified under 13 different parasitic families under the order Hymenoptera whereas the total number of parasitoids belonging to Ichneumonidae was 109 followed by Braconidae (98), Bethylidae (84), Scelionidae (82) and Chalcididae (79). The least number of parasitoids were recorded from the families viz., Aphelinidae (33) and Torymidae (25). The results are in conformity with the findings of Akilandeswari (2000) who found that net sweeping was found better in collecting parasitic insects from Cuddalore district of Tamil Nadu state when compared to other methods employed and Noyes (1989) also reported the same from a forest in Sulawesi, Indonesia. Family wise collection of parasitoids in conventional rice ecosystem revealed that Ichneumonidae (109) and Braconidae (98) were found predominant in net sweeping. Similarly, Ranjith et al. (2015) reported that more than 300 microgastrine wasps belonging to seven genera were collected from sweep net method, among them the polyphyletic genus, Apanteles was the numerically abundant genera in the rice fields of Kerala.

Malaise trap: There was a total of 631 parasitoids belonging to 13 parasitic families gathered using 
Kathirvelu, C. / J. Appl. \& Nat. Sci. 11(1): 164-167 (2019)

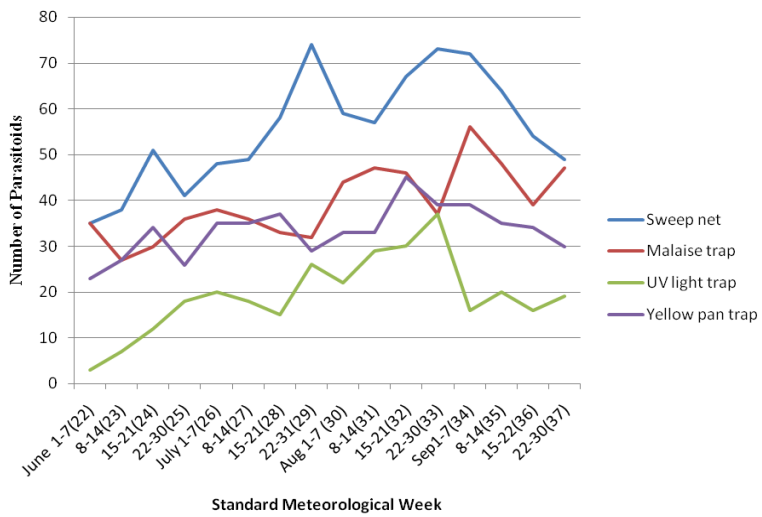

Fig. 1. Parasitoids collected in conventional rice ecosystem using various methods during kuruvai season 2012.

Malaise trap in Kuruvai, 2012 (Fig. 1 and 2). Among the parasitic families Ichneumonidae was collected maximum with 77 numbers followed by Chalcididae (70), Scelionidae (66), whereas the lowest number of parasitoids were recorded from families viz. Aphelinidae (21), Torymidae (20) and Encyrtidae (17). Regarding the population build up of total number of parasitoids, SMW 34 was found with maximum of 56 parasitoids followed by SMW 31 with 47 numbers. In Malaise trap, ichneumonids and chalcidids were recovered maximum when compare to other families. The results corroborate with the findings of Gauld (1991 and 1997) and Bartlett (2000) that confirms Malaise trapping was the best method of collecting Ichneumonidae in Costa Rica.

UV light trap: In UV light trap, there were only nine parasitic families and a total of 308 parasitoids were recorded during Kuruvai 2012 is furnished in Fig.1 and 2. The families viz. Eupelmidae, Eurytomidae, Trichogrammatidae, Aphelinidae were not recorded from UV light trap. The collections of UV light trap revealed that maximum number of prarasitoids (37) were noticed in SMW 33 followed by SMW 32 with 29 numbers. Among the families attracted to light trap, Braconidae was found maximum with 69 numbers followed by Ichneumonidae (65) and Eulophidae (37) meanwhile the lowest number of parasitoids were recorded from the families Bethilidae and Mymaridae with 26 numbers each followed by Chalcididae (18) and Torymidae (9). UV light trap collection showed that a maximum of 69 braconids and 65 ichneumonids followed by 37 Eulophids. The results are in conformity with the findings of Ayoub et al. (1999) who reported that braconids dominance in light trap collection in the tropical moist forest on Barro Colorado Island, Panama.

Yellow pan trap: The parasitoids collected in yellow pan trap during Kuruvai, 2012 in conventional rice ecosystem is shown in Fig. 1 and 2. A total of 534 parasitoids were observed in yellow pan trap in the entire season. The maximum population of

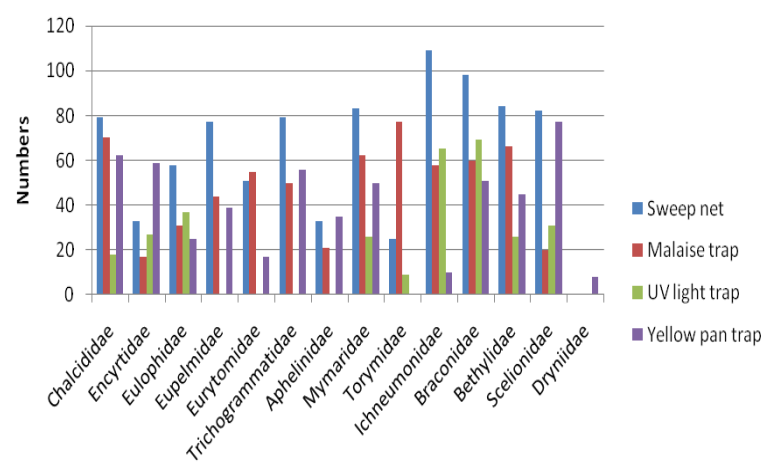

Parasitoid Families

Fig. 2. Parasitic fauna in conventional rice ecosystem during kuruvai season 2012.

parasitoids was evident in SMW 32 followed by SMW 33 and 34 with 39 number of parasitoids each. Among the families collected from yellow pan trap, Scelionidae was found maximum (77) followed by Encyrtidae (59) and Trichogrammatidae (56) while least number of parasitoids were recorded from Eurytomidae (17), Ichneumonidae (10) and Drynidae (8) in yellow pan trap. The collection of scelionids were maximum in yellow pan trap might be due to small size and attraction towards yellow colour.

Regarding the parasitoids in the conventional rice ecosystem, it was evident that there was a gradual increase from the beginning of the season and it reached peak during SMW 29-34 in almost all the methods of collection. The reason might be the population build up of pest in the rice crop during flowering and maturing stage in kuruvai season 2012. This is very much evident from parasitoids collected and identified during the season. The results are tune with the findings of Rani et al. (2007) who studied the diversity of leaf folders and their natural enemies in Madurai District of Tamil Nadu. In contrary, Shiriti Moses (2018) reported the peak activity period for most of the rice insect pest was observed during the $33^{\text {rd }}$ standard week of August to $40^{\text {th }}$ standard week of October in Pusa, Bihar. Diversity indices of insect pests and their natural enemies were found to be affected by the combined effect of rice growth stages and management practices (Bakar and Khan, 2016)

Further, Wilby et al. (2006) reported that land use and management controlled the biodiversity associated with rice crop. Further, he narrated that the crop and vegetation richness was also found to some positive effects of arthropod species during tillering and flowering stages of rice crop.

\section{Conclusion}

The diversity of parasitic fauna of conventional rice ecosystem during kuruvai 2012 indicated that the presence of 13 parasitic families. Among the families collected Ichneumonidae, Braconidae, Sclio- 
nidae and Chalcididae were found predominant. Dryniidae was recorded only in yellow pan trap. Among the collection methods employed, Net sweep was found to be the best in collection of parasitoids than other methods.

\section{ACKNOWLEDGEMENTS}

The author is thankful to the authorities of Annamalai University for their permission to carry out this study at Annamalainagar, Tamil Nadu.

\section{REFERENCES}

1. Akilandeswari, G. (2008). Studies on the parasitic fauna of major agroecosystems in the coastal belt of Cuddalore district. M.Sc. (Ag.) Thesis, Faculty of Agriculture, Annamalai University, Annamalainagar, Tamil Nadu, India.

2. Arora, R. and G.S. Dhaliwal (1996). Agro-ecological changes and insect pest problems in indian agriculture. Ind. J. Ecol., 23:109-127.

3. Ayoub, N.A., Pickering, J., Sharkey, M. and D.Windsor (1999). Nocturnal and diurnal parasitic wasp activity in the canopy versus understory of the tropical moist forest on Barro Colorado Island, Panama.

4. Bartlett, R. (2000). Efficiency of collection methods and flight activity of Ichneumonidae (Hymenoptera) in three sites in Guanacaste, Costa Rica. M.Sc. Thesis, The University of Georgia, Athens, Georgia.

5. Bakar, M. A. and Khan, M. M. H. (2016). Diversity of insect pests and natural enemies as

6. influenced by growth stages and pest management Practices in Rice. Bangladesh J. Agril. Res. 41(3): 461-470.

7. Boucek, Z. (1988). Australasian Chalcidoidea (Hymenoptera): A bio systematic revision of the genera of fourteen families, with a re-classification of species. CAB International, Wallingford, 832p.

8. Brown, B.V. (1993). A further chemical alternative to critical point drying for preparing (small or large) flies. Fly Times, 7:10.

9. Dale, D. (1994). Insect pests of rice plant, their biology and ecology. Pp. 363 - 485. In: Heinrichs, E.A. (ed). Biology and management of rice insects, Willey Eatern Ltd., Newyork.

10.Gauld, I.D. (1991). The Ichneumonidae of Costa Rica, 1. Memoirs of American Entomological Institute, $47: 1-589$.

11.Gauld, I.D. (1997). The Ichneumonidae of Costa Rica, 2. Memoirs of American Entomological Institute, $57: 1-485$.

12.Heinrichs, E.A. (1994). Impact of insecticides on the resistance and resurgence of rice plant hoppers. IRRI, Manila, Philippines. 162p.

13.Juliano, B.O. (1993). Rice in human nutrition. FAO and IRRI, Philippines. 162p.

14.Kiritani, K. (1979). Pest management in rice. Annu. Rev. Entomol. 24, 279-312.

15.Naganagoud, A., Patil, B.V. and Sreenivas, A.G. (1999). Studies on the light trap catches of major pests of rice in Tungabhandra project area. Karnataka J. Agrl. Sci. 12:191-194.

16.Noyes, D.J. (1982). Collecting and preserving chalcid wasps. J. Nat. Hist., 16: 315-334.

17.Noyes, J.S. (1989). A study of five methods of sampling Hymenoptera (Insecta) in a tropical rain forest with special reference to the Parasitica. J. Nat. Hist., 23: 285-298.

18.Ooi, P.A.C. and Shepard, B.M. (1994). Predators and parasitoids of rice insects' pests. In: Heinrichs, E.A. (eds). Biology and management of rice insects. Willey Eastern Ltd., New York . 585-612.

19.Pandya, S.K., Senapati, B. and Samalo, A.P. (1995). Field efficacy of some insecticides against rice plant hoppers and their predators. Pestology, 19(8):15-19.

20.Pathak, M.D. (1997). Insect pests of rice. IRRI, LOS Banos, $77 \mathrm{p}$.

21.Pathak, M.D. and Khan, Z.R. (1994). Insect pests of rice. IRRI, Philippines. 89p.

22.Pushpakumari, A.S. and Tiwari, S.N. (2005). Incidence and population dynamics of rice pests and their natural enemies in Uttaranchal. Pestology, 29 (2):9-13.

23.Rai, A.K., Sinha, R.B.P., and Singh, A.K. (2000). Effect of abiotic factors on the population of rice leaf folder, Cnaphalocrocis medinalis. Ann. Plant Prot. Sci., 8:154-158.

24.Rani, W.B., Amutha, R., Muthulakshmi, S., Indira, K. and Mareeswari, P. (2007). Diversity of rice leaf folders and their natural enemies. J. Agri. Biol. Sci. 3(5): 394-397.

25.Ranjith, A.P, Veena, T., Rajesh, K.M. and Nasser M. (2015). Diversity, abundance and host-parasitoid association of Microgastrine (Hymenoptera: Braconidae) wasps in rice fields of Kerala. Proceedings of the National Workshop on the Identification of Bees, Wasps, Beetles and Bugs. 27-28 Feb. 2015.

26.Rao, P.K., and Ali, M.H. (1976). Some natural enemies of rice and sorghum stem borers in Andhra Pradesh. Ind. J. Ent., 38:191-193.

27.Shriti Moses (2018). Studies on diversity of parasites and predators associated with major

28.insect pests of rice. M.Sc.Thesis. Dept. of Entomology, Dr. Rajendra Prasad Central Agricultural University Pusa (Samastipur), India

29.Singh, J. and Dhaliwal,G.S. (1994). Insect pest management in rice: A perspective. In: Dhaliwal, G.S. and Arora, R. (eds). Trends in Agricultural Pest Management. Common wealth publishers, New Delhi. 56-122

30.Townes, H. (1972). A light weight Malaise trap. Entomol. News, 83: 239-247.

31.Way, M.J. and Heong, K.L. (1994). The role of biodiversity in the dynamics and management of insect pests of tropical irrigated rice. Bull. Entomol. Res., 84: 567-587

32.Wilby, A., Lan, L.P., Heong, K.L., Huyan, N.P.D., Quang, N.H., Minh,N.V. and Thomas, M.B. (2006). Arthropod diversity and community structure in relation to land use in the Mekong Delta, Vietnam. Ecosystems, 9: 538-549. 